\title{
A Study on the Reform of Basic English Teaching for English Majors at Application-Oriented Universities
}

\author{
Cuiping Han \\ Humanities and international Education College, Xi'an Peihua University, Chang'an Campus, Xi’an, China \\ 406241560@qq.com
}

Keywords: applied talent; basic English teaching; current situation; reform strategies

\begin{abstract}
In order to adapt to the development of the new science and technology, local colleges and universities are all transforming to application-oriented universities and the training of application-oriented talents to adapt to the development of times is the focus of current university transformation development. The ministry of education has also put forward new requirements for the cultivation of English professionals. As the core curriculum of English majors, basic English is crucial to the cultivation of applied talents in line with the development of times. However, there are still many problems in basic English teaching, which hinder the cultivation of talents. Combining with the needs of cultivating applied talents, this paper analyzes the existing problems in basic English teaching and proposes reform strategies, thus laying a foundation for cultivating applied talents.
\end{abstract}

\section{Introduction}

With the development of science and technology and the growth of international exchange, our society needs more practical talents. In order to adapt to the development of the situation, some local universities are transforming into application-oriented universities. In this transition, college students should not only have the ability as specialized talents who have received higher education, but also have the ability to apply professional knowledge they have learned into practice. In the context of this transformation, the ministry of education has put forward new requirements for English teaching in universities. The teaching for English majors needs to transform to the direction of cultivating students' English practical ability. After graduation, students can be qualified for the jobs and quickly gain more work experiences.

Basic English is one of the main core courses required for undergraduate students in their first and second year of English majors and the basic English teaching lays a solid foundation for students to continue to develop their professional skills, expand their professional knowledge and cultivate their relevant practical ability in senior grades. This course is the most elementary, most comprehensive, most extensive, and most effective one to cultivate students to be all-round people in the English professional curriculum system. The teaching quality of this course directly affects the quality of English professional personnel training. Basic English course is a compulsory course for English majors in colleges and universities, which plays a crucial part in expanding students' basic English knowledge and cultivating their comprehensive application ability.

According to the study made by the author, however, it was found that at present the basic English teaching for English majors tends to stress their imitation and memory in language skills training, but neglecting to cultivate students' ability in thinking, innovating, problem-solving and problem-analyzing. As a result, English major graduates, compared with other liberal arts graduates, are weak in the humanities comprehensive quality. There are obvious deficiencies in their thinking ability in width and depth and their knowledge structure, so it is imperative to explore new effective teaching mode and method to change such situation. By analyzing the current situation of basic English teaching in college for English majors, this paper shows that there are many problems in basic English teaching for English majors in China, such as the simplification of its teaching model, boring classroom teaching, students' lack of enthusiasm for learning English, from which it is 
concluded that it is a necessity to reform the teaching of basic English. Therefore, college English teaching mode must be reformed and innovated completely, improving the basic English teaching methods, arousing students' interest in English learning and stimulating their learning enthusiasm so as to improve the effectiveness of English teaching and cultivate talents who can meet up with the standard as experienced and multiple talents with ability in colleges and universities.

\section{Current situation of Basic English Teaching}

\subsection{Teachers lack of innovation in teaching concept and lay stresses on theory over practice}

According to "the syllabus of English courses for English majors of institutions of higher education”, the teaching of basic English course should improve students in their listening, speaking, reading, writing and translating abilities. But in the actual classroom teaching process, teachers are the main participants of the classroom activities and they are the actual controllers of the classroom activities. During their classroom teaching, teachers were busy most of the time with analyzing the text structure, sentence structure, focusing on the grammar, words and expressions, and the background information of the article, which are the emphasis of the traditional English teaching mode, stressing particularly on students' understanding of the grammar knowledge. Thus students in classroom rarely have chances to express themselves. There are few opportunities for students to cooperate in learning or to discuss to gain knowledge. Thus they have low participation in class and have poor interaction with teachers and their classmates, so they can only passively take in the knowledge taught in class. On the other hand, basic English teaching attaches great importance to theory over practice, and classroom teaching design focuses on syntactic knowledge and discourse structure, which seldom involves the practical application of English in authentic life, hardly stimulating students' creativity of thinking and improving their application ability.

\subsection{With the classroom teaching content dull and boring and the single teaching method used, it is difficult to arouse students' interest in English learning}

The content of some texts are obsolete, which are deviated from life and make students lack of interest, hardly arousing students' emotional resonance. Listening and speaking training activities which are relevant to the textbook cannot make students acquire the language used in the authentic English context. In addition, basic English teaching attaches too much emphasis on improving students' ability in discourse understanding and text analysis, and teachers ignore the general knowledge teaching penetrated from the text. Although students have a good grasp of the vocabulary, grammar and discourse structure through intensive learning of the text, while they know little about the humanistic knowledge the theme reflected in each unit, leading to the poor improvement of students' humanistic quality and their lack of social humanities knowledge.

\subsection{There lack activities in the second class}

At present, most teachers pay more attention to classroom teaching in the teaching process of basic English and neglect to cultivate students' innovation ability through the second class activities. Students lack the opportunity to use English in the authentic context, so it is difficult for them to make bold attempts to find, analyze and solve problems independently, which results in their poor ability to employ English in the real context. The teaching of basic English in college English major should aim to cultivate students' language ability and language application ability. And in the process of curriculum reform of "basic English" for English majors in colleges and universities, the philosophy of education can not keep up with the development of society. Even though some teachers carry out the second classroom activities, due to the limited activities in the second classroom and with student's education content relatively narrow, they failed to arouse the students' interests and thus failed to cultivate their ability of using English.

\subsection{Single assessment method and assessment system cannot reflect their real ability of the} applied talents

The traditional basic English assessment method mainly evaluates students' learning effect by 
means of examination, and its evaluation standard is limited to the test score. Therefore, students focus on reviewing the limited content acquired in the classroom before examination in order to obtain higher scores, which cannot reflect their real English learning level. Besides, the examination method of test paper alone can not comprehensively enhance students' English ability, especially students' English application ability employed in the authentic English environment. Even though some teachers in the current classroom teaching activities take the form of process assessment which takes up a certain proportion and change the situation that the ability of the student is judged from his test score of his final exam, the test content still focuses on discourse analysis, words and syntax application acquired in classroom, and still fails to test students' ability to actually employ English in daily life.

\section{Some reform strategies for Basic English teaching}

\subsection{It's necessary to change the teaching concept of teachers and their traditional role in classroom}

The new "syllabus of English courses for English majors of institutions of higher education", which is simplified as "the new syllabus" in the following paragraphs, states that classroom teaching should be student-centered and teacher-led, changing the teacher-centered teaching model in the past and focusing on cultivating students' learning ability and research ability. Then how to change basic English teaching method from "teacher-centered" to "student-centered"? How to adjust the relationship between teaching and learning?

First of all, the teacher should change from the traditional role of "imparting knowledge and solving doubts for the students" to a new one, that is, the teacher should first be the active advocate and guide to help students to develop their independent innovation learning ability, letting students fully realize the importance and necessity of self-learning and independent learning, guiding and helping students to transform from the maintenance study to innovative self- learning, cultivating students' ability of self- learning and independent learning, finally and eventually changing their concept of "learn to know" to "know to learn".

Second, the teachers are designers and managers of classroom teaching and classroom activities, specifically, teachers should reasonably design, according to the requirements of "the new syllabus", teaching tasks of listening, speaking, reading and writing for students, let students know clearly the goal and direction of their own efforts and guide students to actively and effectively participate in classroom activities. Furthermore, the course teacher is also a trainer of students' learning skills, who can share some learning experience and methods with their students by holding lectures and organizing seminars for them, and encourage students to explore effective learning strategies and skills. Finally, the teacher also can help the student to analyze and solve questions independently. Therefore, the role of new teachers is much richer and more important than that of traditional teachers.

\subsection{Teachers should adjust their teaching methods to improve students' participation in class}

"The new syllabus" clearly states the importance of the adjustment of teaching methods. It pointed out that "the teaching method of professional courses is directly related to the cultivation and improvement of students' abilities in various aspects." Teachers should carry out more task-centered and diversified teaching activities. While strengthening the basic training, the teaching methods of heuristic, discussant, discovery and research are adopted to fully mobilize the students' enthusiasm for learning, stimulate their learning motivation and maximize the participation of students in the whole process of learning. The teacher should design proper teaching activities for each lesson carefully, use the classroom teaching method which favors the student to participate more teaching activities, let the student participate the entire process of teaching. For example, in the background knowledge section of each unit, students are encouraged to use vocabulary and sentences related to the topic by discussing theme-related issues, which not only enables students to understand the background knowledge related to the text, but also further 
applies relevant practical sentences to improve students' ability to use English in daily life. In the teaching of the text, the task-driven teaching method is adopted. By assigning relevant tasks to students and guiding them to complete tasks by reading articles, students' reading ability is not only improved, but also the situation of passive listening to lectures caused by the teacher being the only performer in the classroom is avoided". Adopting enlightening and discovering teaching methods can inspire and encourage students to think positively. The mode of flipped classroom should be adopted. Teachers should make full use of the internet as effective teaching tools, before teaching a new unit, they can offer the relevant teaching material on line and assign some tasks about the text to guide the students to have a self-study in advance which can help students to have class effectively and help them think independently. By asking questions not fully understood and finding solutions to problems independently in and out of classroom, students can compare the nuances and usages of synonyms or antonyms, solving problems through their own effort. By using different teaching methods, teachers can not only liven the classroom atmosphere, but more importantly, arouse students' interest in learning. Students can gain more by actively participating in classroom activities, and their ability can also be improved continuously.

\subsection{The second class activities should be Reasonably carried out so as to enrich students' practical activities}

The second class activity is the effective supplement and further extension of basic English classroom teaching activities. The rich and colorful second class activities can not only expand students' knowledge, but also improve their English application ability. “The new syllabus” points out that "extracurricular learning and practice is an extension and expansion of classroom teaching and an important way to cultivate and develop students' abilities, which should be carried out purposefully, planned and organized under the guidance of teachers." Therefore, in addition to classroom teaching, it is of great importance to guide students to participate in corresponding second class activities and practical activities. It is important to Conduct such activities as drama performance, English speech contest, contest of English writing, English reading contest, funny English dubbing, which can not only reinforce the basic English knowledge they learned in class, but also can motivate students creatively apply the knowledge they acquired into real life scenarios, not only arousing students' interest in learning English meanwhile strengthen the students' English ability of innovation. It is also the embodiment of cultivating students' to be practical talents. Although we may encounter various difficulties in the process of carrying out the second class activities, from the implementation effect, most of the students have greatly improved their comprehensive English application ability, especially their listening and speaking ability and gain more effective skills of learning English by taking part in various second class activities. In addition, the system also enhances the comprehensive quality of students, for example, their ability to cooperate with each other was improved in a English drama team, and the skills used to express themselves and to communicate with others are improved through participating in speech contests, etc, and students become more confident than before. Students, in particular, are surprisingly innovative and expressive which is beneficial to cultivate the comprehensive ability of the students.

\subsection{Assessment methods should be reformed and process assessment should be strengthened}

We will reform the situation in which the final exam is the primary assessment to judge students' ability and the process assessment is the secondary one. Besides, the disadvantage of final exam as the main assessment method is that it can't truly reflect the real level of students' learning and discourage them from exploring new knowledge. Students used to feel depressed when they failed their exams and lose motivation and confidence in their studies. Therefore, both teachers and students should turn their attention from examination to the process of study itself, and the reform of assessment methods is imperative. First of all, teachers should abandon the traditional practice of teaching students to deal with mechanical and boring grammar and vocabulary exercises, and design some effective and efficient practice or activities that enable students to freely and creatively use the English language, improve students' interest in their participation in learning so as to improve students' learning efficiency. Secondly, the assessment content and methods of basic 
English courses need to be reformed urgently, and the assessment method of combination of formative evaluation and final assessment should be adopted, each accounting for $50 \%$ of the total score. The final examination still takes the form of paper test and the test subjects of CET-4, CET-6 and TEM4, including vocabulary, grammar, reading comprehension, translation, writing, are adopted, which are closely combined with the teaching materials, and are based on the basic theoretical knowledge taught in this semester. Through this way, it can reasonably and comprehensively evaluate students' performance in their classroom. The formative assessment is divided into in-class assessment and after-class assessment. In-class assessment includes pre-class demonstration, group discussion, answering questions, etc. After-class assessment includes participation in English extracurricular activities, participation in various English competitions at all levels, etc. Only through reforming the examination method and the assessment mode, combining the students' performance in class and after class can we truly reflect the students' real level, and further promote teachers' effective teaching and students' efficient learning.

\section{Conclusion}

Basic English, as core course for students majoring in English, plays a key part in cultivating the comprehensive abilities of English majors in their listening, speaking, reading, writing and translating, especially in cultivating students to be applied talents to satisfy the needs of development and to keep up with the development of society. Only teachers really change their teaching concept, employ flexible teaching methods, carry out various second classroom activities and adopt a reasonable assessment methods in the process of teaching, they can really stimulate students' creativity, improve students' English application ability, thus cultivate them to be the applied talents.

\section{References}

[1] College foreign language teaching committee English group. College English major syllabus. [M]. Shanghai foreign languages education press, 2000.

[2] Chang Junjue, Jinxue. Problems existing in basic English teaching contents of core compulsory courses and Suggestions for reform. [J]. Foreign Languages Research, 2012(6):54-58.

[3] Gao Fengxia. Innovative talent training and basic English teaching reform. [J] Journal of Bingtuan Education Institute, 2013(2): 62-64.

[4] Hu Meihong. Discussion and practice of basic English teaching reform in higher English major. [J] Journal of Changshu college, 2002(5):95-96.

[5] Yin Qian. Reflections on the Reform of the basic English courses for English majors in Universities. Journal of Xin yi Normal University for Nationalities, 2018(1):110-112.

[6] Zou Yanli. Reform on Teaching Model of Basic English Course of English Majors. Higher Education Research. 2012(4):215-216.

[7] Zhang Zhicong. Reflections on the reform of basic English teaching in higher English major. [J]. Journal of Chongqing University of Science and Technology (Social Science Edition), 2010(4); 187-188.

[8] Zhou Jing. Reform of basic English practice teaching in higher English major. [J]. Innovation Education. 2012.. 